\title{
HYPOVITAMINOSIS D IN CHILDREN WITH TYPE 1 DIABETES MELLITUS AND ITS INFLUENCE ON BIOCHEMICAL AND DENSITOMETRIC PARAMETERS
}

\author{
Jarmila Vojtková, Miriam Čiljaková, Lenka Vojarová, Katarína Janíková, Zuzana Michnová, Veronika Šagiová
}

Department of Pediatrics, Comenius University in Bratislava, Jessenius Faculty of Medicine and University Hospital in Martin, Slovakia

Summary: The aim of the study was to establish the frequency of hypovitaminosis D in children with type 1 diabetes mellitus (T1D), its influence on biochemical and densitometric parameters and the relation to diabetic nephropathy. 58 children with T1D at the age 9-19 years were enrolled to the study. Vitamin D concentration less than $30 \mathrm{ng} / \mathrm{ml}$ was considered as insufficient. 37 children (63.79\%) had vitamin D level under $30 \mathrm{ng} / \mathrm{ml}$, from these 19 subjects (32.7\%) had vitamin D level under $20 \mathrm{ng} / \mathrm{ml}$ and 2 subjects $(3.44 \%$ ) under $10 \mathrm{ng} / \mathrm{ml}$. Children with vitamin D deficiency had significantly lower magnesium concentration and lower $\mathrm{Z}$ score of lumbar spine $(-1.34 \pm 1.24$ vs. $-0.30 \pm 1.21, \mathrm{p}=0.01)$ compared to diabetics with sufficient vitamin $\mathrm{D}$ concentration. No significant difference was found in parameters calcium, phosphorus or glycosylated hemoglobin. Patients with diabetic nephropathy $(n=18)$ showed no significant difference in vitamin $D$, glycosylated hemoglobin or Z score of lumbar spine compared to the patients without nephropathy $(n=40)$. Subjects with nephropathy had significantly longer diabetes duration, significantly higher cholesterol and triacylglycerol concentration. In our cohort of patients nearly two thirds of children had insufficient vitamin D concentration what supports the need to monitor and eventually supplement vitamin D in T1D subjects.

Key words: Vitamin D deficiency; Type 1 diabetes mellitus; Biochemical and densitometric parameters

\section{Introduction}

Vitamin D represents a group of steroid hormonal precursors necessary for the synthesis of calcitriol - the hormon with important role in the calcium-phosphate metabolism and right bone formation (21). According to the recent information vitamin D also regulates the cell growth and differentiation, induces apoptosis of neoplastic cells, has immunomodulatory effect (2) and can prevent the cardiovascular diseases $(13,14,33)$. Maternal vitamin D deficiency during pregnancy may lead to impaired fetal growth and bone development (4). In relation to carbohydrate metabolism, it can increase the pancreatic insulin secretion (23) and its deficit is associated with impaired glucose tolerance (25). Even $80 \%$ of vitamin D source is sunshine. Ultraviolet irradiation (UVB at wavelenghts $280-315 \mathrm{~nm}$ ) splits provitamin 7-dehydrocholesterol in the skin into provitamin $\mathrm{D}_{3}$ which can spontaneously change itself into an isomer, cholecalciferol, uptaken by the liver. About $20 \%$ of cholecalciferol comes from animal food sources (fish oil, liver, eggs, milk) absorbed through the intestine. In the liver, 25-hydroxycholecalciferol (25-OHD) arises by 25-hydroxylase. 25-OHD is the main form of vitamin D in the circulation, represents the majority of vitamin D reserves in the liver (22) and its huge part passes into the bile (enterohepatic circulation). The next important organ in vitamin D metabolism is kidney (16), where 1,25- dihydroxycholecalciferol $\left[1,25(\mathrm{OH})_{2} \mathrm{D}\right]$ or calcitriol arises by $\alpha 1$-hydroxylase. Normal concentration of serum vitamin $\mathrm{D}_{3}$ is $30-100 \mathrm{ng} / \mathrm{ml}$, concentration less than $30 \mathrm{ng} / \mathrm{ml}$ is considered as insufficient (Table 1).

Nowadays, many studies claim about increasing deficit of vitamin D in whole children and adolescent population $(9,12)$. The presence of type 1 diabetes mellitus (T1D) may even enhance this number (8). The prevalence of insufficient vitamin $\mathrm{D}$ level in subjects with diabetes mellitus varies between 50-90\% according to different authors $(19,20)$ and may have relation to intestine microangiopathy with insufficient absorption or to nephropathy with inability of kidney to hydroxylate $25-\mathrm{OHD}$ into $1,25(\mathrm{OH})_{2} \mathrm{D}$

The aim of the study was to establish the prevalence of vitamin D deficiency in children with type 1 diabetes mellitus, to compare the biochemical and densitometric parameters between patients with insufficient and normal level of vitamin D and to find if diabetic nephropathy influenced these parameters.

\section{Material and Methods}

The study was approved by Ethical Commitee of Jessenius Faculty of Medicine in Martin, Slovakia and was performed according to the Declaration of Helsinki. Enrolled criteria were signed informed consent, age 9-19 years, diagnosed type 1 diabetes mellitus (T1D) based on criteria of 
Tab. 1: Vitamin D concentrations

\begin{tabular}{|l|l|}
\hline Normal value of vitamin D & $30-100 \mathrm{ng} / \mathrm{ml}$ \\
\hline Insufficiency of vitamin D & $20-30 \mathrm{ng} / \mathrm{ml}$ \\
\hline Deficit of vitamin D & $10-20 \mathrm{ng} / \mathrm{ml}$ \\
\hline Severe deficit of vitamin D & $<10 \mathrm{ng} / \mathrm{ml}$ \\
\hline
\end{tabular}

American Diabetes Association. Subjects were investigated during autumn time from September to November 2010. Immobile patients, patients treated by corticoids, by calcium, magnesium or vitamin D supplements and subjects with known diseases of calcium-phosphate metabolism (parathyreosis disorder, tetania, rachitis, other) were excluded from the study. Subjects with acute condition (respiratory infection, ketoacidosis) were enrolled to the study the soonest in 4 weeks after recovering.

Diabetes onset, diabetes duration and basic anthropometric parameters (weight, height, body mass index - BMI) were noticed in each patient. Microalbuminuria and so the presence of eventual diabetic nephropathy was investigated from 12-hour night urine sample while good glycemia compensation, normal blood pressure and without excessive physical activity. Patients had drawn $5 \mathrm{ml}$ of venous blood, from which biochemical parameters - total calcium $(\mathrm{Ca})$, ionized calcium $\left(\mathrm{Ca}^{2+}\right)$, phosphorus $(\mathrm{P})$, magnesium $(\mathrm{Mg})$, cholesterol, triacylglycerol and glycosylated hemoglobin (HbA1c) were established by standard biochemical methods and vitamin $\mathrm{D}_{3}$ level by commercial kit Roche ${ }^{\circledR}$ Elecsys2010. All patients had examined densitometry by Hologic Discovery Bone Densitometer and Z score of lumbar spine and femur were established. The results were correlated considering the age, sex and "height age" (the age which reflects the child's height according to the 50th percentile of growth tables) (10).

The results were statistically processed by system MS Excel 2007. Numeric variables were parametrically distributed and were expressed as mean with standard deviation. To assess significant difference between subgroups Student's t-test was used and $\mathrm{p}$ less than 0.05 was considered statistically significant.

\section{Results}

58 children, 30 boys and 28 girls, with type 1 diabetes mellitus at the age 9-19 years (average $13.91 \pm 2.95$ years) were enrolled to the study. 21 children $(36.21 \%)$ had normal concentration of vitamin $\mathrm{D}$, however in 37 children $(63.79 \%)$ insufficient vitamin D level (under $30 \mathrm{ng} / \mathrm{ml}$ ) was found. From these patients 19 subjects $(32.7 \%)$ had vitamin D level under $20 \mathrm{ng} / \mathrm{ml}$ and 2 subjects (3.44\%) under $10 \mathrm{ng} / \mathrm{ml}$ (Figure 1).

Children with insufficient level of vitamin D had significantly lower magnesium concentration $(0.79 \pm 0.09 \mathrm{mmol} / \mathrm{l}$ vs. $0.84 \pm 0.08, \mathrm{p}<0.05)$ and significantly lower total $\mathrm{Z}$ score of lumbar spine densitometry $(-1.34 \pm 1.24$ vs. $-0.30 \pm 1.21$, $\mathrm{p}=0.01)$ compared to the children with normal vitamin D level (Figure 2). No significant difference was found in
2

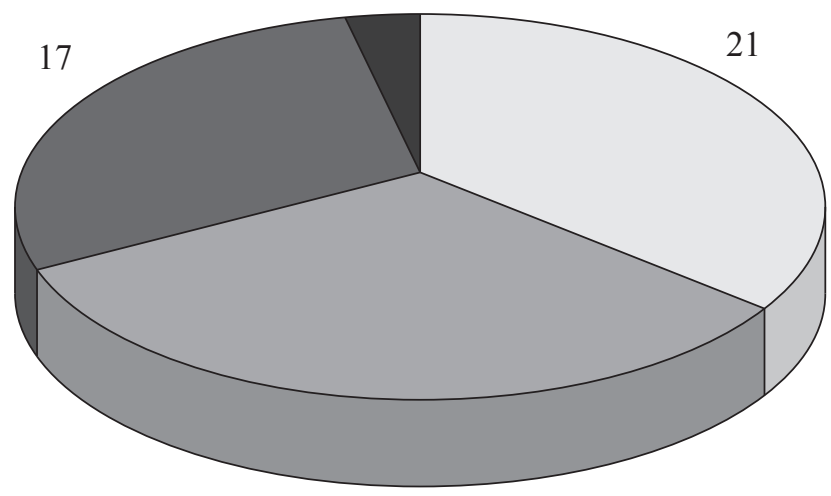

18

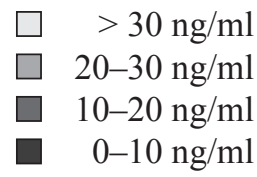

Fig. 1: Vitamin D level in children with diabetes mellitus

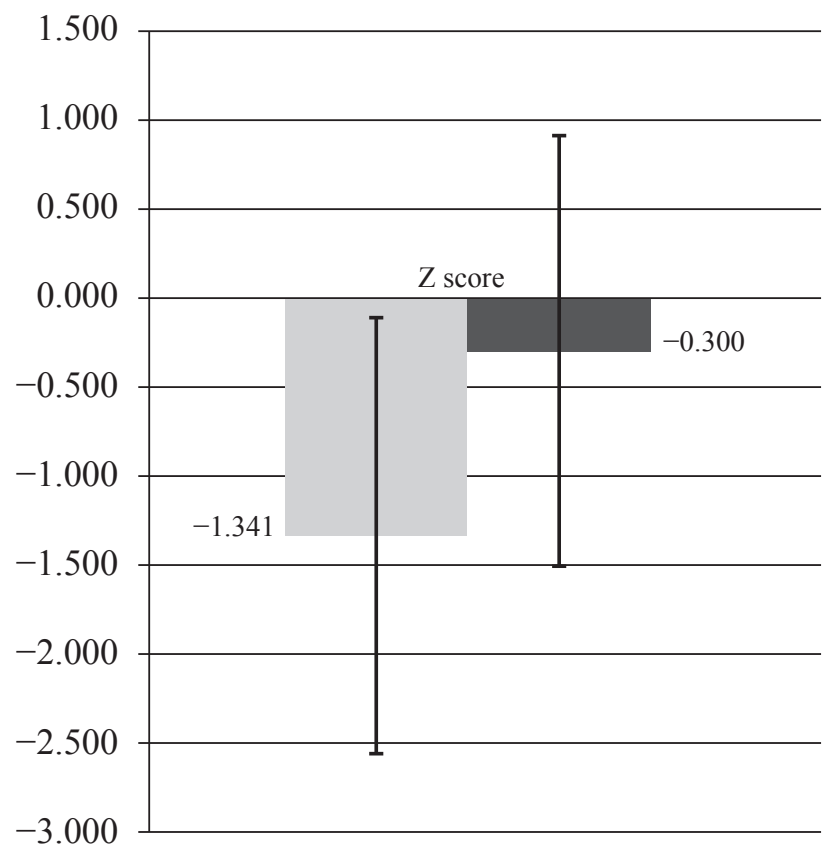

children with insufficient vitamin D level children with normal vitamin D level

Fig. 2: Significantly lower $Z$ score of lumbar spine densitometry in children with insufficient vitamin D level 
Tab. 2: Differences in measured parameters between children with insufficient and sufficient level of vitamin D

\begin{tabular}{|l|c|c|c|}
\hline & $\begin{array}{c}\text { Children with insufficient level } \\
\text { of vitamin D (n= 37) }\end{array}$ & $\begin{array}{c}\text { Children with sufficient level } \\
\text { of vitamin D (n = 21) }\end{array}$ & p \\
\hline Diabetes duration (years) & $5.46 \pm 4.07$ & $5.30 \pm 4.00$ & $>0.05$ \\
\hline Diabetes onset (years) & $7.85 \pm 4.09$ & $9.55 \pm 3.71$ & $>0.05$ \\
\hline $\mathrm{Ca}(\mathrm{mmol} / \mathrm{l})$ & $2.43 \pm 0.12$ & $2.47 \pm 0.12$ & $>0.05$ \\
\hline $\mathrm{Ca}^{2+}(\mathrm{mmol} / \mathrm{l})$ & $1.20 \pm 0.11$ & $1.22 \pm 0.09$ & $>0.05$ \\
\hline $\mathrm{P}(\mathrm{mmol} / \mathrm{l})$ & $1.39 \pm 0.24$ & $1.36 \pm 0.25$ & $>0.05$ \\
\hline $\mathrm{Mg}(\mathrm{mmol} / \mathrm{l})$ & $0.79 \pm 0.09$ & $0.84 \pm 0.08$ & $<\mathbf{0 . 0 5}$ \\
\hline $\mathrm{HbAlc}(\%)$ & $10.62 \pm 2.84$ & $10.49 \pm 1.92$ & $>0.05$ \\
\hline Cholesterol (mmol/1) & $4.64 \pm 1.08$ & $4.59 \pm 0.99$ & $>0.05$ \\
\hline Triacylglycerol (mmol/l) & $1.25 \pm 0.77$ & $1.36 \pm 1.02$ & $>0.05$ \\
\hline BMI (kg/m $)$ & $19.32 \pm 3.52$ & $20.23 \pm 3.70$ & $>0.05$ \\
\hline Microalbuminury (mg/l) & $8.09 \pm 10.47$ & $8.57 \pm 16.11$ & $>0.05$ \\
\hline Z score lumbar spine & $-1.34 \pm 1.24$ & $-0.30 \pm 1.21$ & $=\mathbf{0 . 0 1}$ \\
\hline Z score femur & $-1.04 \pm 0.96$ & $-0.50 \pm 0.70$ & $=0.06$ \\
\hline
\end{tabular}

parameters like diabetes duration, total or ionized calcium, phosphorus, glycosylated hemoglobin, cholesterol and triacylglycerol between these two groups (Table 2).

Based on microalbuminury, incipient nephropathy was established in 18 diabetic patients. No significant difference was found in vitamin D concentration, calcium, phosphorus, magnesium, glycosylated haemoglobin or Z score densitometry between diabetic patients with or without nephropathy. Patients with nephropathy had significantly longer diabetes duration $(7.77 \pm 3.58$ years vs. $4.40 \pm 3.79, \mathrm{p}=0.001)$, significantly higher cholesterol $(4.96 \pm 0.77 \mathrm{mmol} / \mathrm{l}$ vs. $4.48 \pm 1.12$, $\mathrm{p}<0.05)$, triacylglycerol level $(1.70 \pm 0.97 \mathrm{mmol} / \mathrm{l}$ vs. $1.11 \pm$ $0.75, \mathrm{p}<0.05)$ and body mass index $\left(20.97 \pm 3.71 \mathrm{~kg} / \mathrm{m}^{2}\right.$ vs. $19.05 \pm 3.39, \mathrm{p}<0.05)$ compared to the patients without nephropathy (Table 3 ).

\section{Discussion}

Association of diabetes mellitus with disorder in bone metabolism and changes in vitamin D level is not completely understood. At least three hypotheses exist about the relation of these clinical units. It could represent two separate problems, probably as a consequence of improper eating habits and insufficient sunbathing (26). Another possibility is that diabetes mellitus is a cause for vitamin D deficiency $(6,20)$ as a consequence of intestine microangiopathy with insufficient absorption or kidney inability to hydroxylate 25-OHD into $1,25(\mathrm{OH})_{2} \mathrm{D}(29)$. The third hypothesis is that vitamin $\mathrm{D}$ deficiency is one of the factors predisposing to diabetes mellitus $(24,32)$ what is supported by new information about immunomodulatory impact of vitamin D (1). Insufficient level could predispose to origin of allergy (17, 18 ) or autoimmune diseases as type 1 diabetes mellitus.

Nowadays, a lot of studies claim about decreased level of vitamin $\mathrm{D}$ in diabetic patients with prevalence $50-90 \%$ according to the different authors $(19,20)$. Deficit of vitamin D was significantly more frequent $(90.6 \%)$ and vitamin D level was significantly lower in diabetic children under 16 years compared to the healthy children $(85.3 \%)$ with matched age (3). Sufficient level of vitamin D was established in less than $25 \%$ of 128 patients with T1D (30). Subjects with vitamin D deficit had significantly longer diabetes duration and were significantly older (at the age 12-18 years). Similarly, significantly lower vitamin D concentration was found in 26 diabetic patients compared to 15 non-diabetic patients (34). In our group of patients, vitamin D deficiency was found in $63.79 \%$ of patients with T1D and subjects with insufficient level of vitamin D had significantly lower bone density of lumbar spine compared to the patients with normal value of vitamin D. No significant differences were found in serum phosphorus, total and ionized calcium level between observed groups of patients, what may reffer to adequate compensation mechanisms maintaining the normal concentration of these ions.

Magnesium is essential for the formation of $1,25(\mathrm{OH})_{2}$ vitamin $\mathrm{D}_{3}$, adequate function of the parathyroid glands and sensitivity of target tissues to parathyroid hormone and vitamin D (35). Magnesium deficit is associated with hypoparathyroidism, low production of active vitamin D metabolites and resistance to parathormone and vitamin D (7). Several studies have shown that magnesium supplementation may improve bone mineral density (31). Magnesium is also critical for insulin sensitivity and its release. In subjects with type 2 diabetes, hypomagnesemia may worsen insulin resistance (28). Hypomagnesemia is usually seen in subjects with diabetes mellitus especially in those with inadequate compensation. Hyperglycemia is associated with magnesiuria and calciuria as the kidney is not able to reabsorb these ions (15). Absorption of magnesium through small intestine is primarily via passive diffusion independent of vitamin $\mathrm{D}$, however vitamin D supplementation increases magnesium absorption (11). Calcium and magnesium absorption 
Tab. 3: Differences in measured parameters between children with and without diabetic nephropathy

\begin{tabular}{|l|c|c|c|}
\hline & $\begin{array}{c}\text { DM with incipient nephropa- } \\
\text { thy (n= 18) }\end{array}$ & $\begin{array}{c}\text { DM without nephropathy (n } \\
\mathbf{= 4 0}\end{array}$ & p \\
\hline Diabetes duration (years) & $7.77 \pm 3.58$ & $4.40 \pm 3.79$ & $=\mathbf{0 . 0 0 1}$ \\
\hline Diabetes onset (years) & $7.71 \pm 3.04$ & $8.75 \pm 4.35$ & $>0.05$ \\
\hline $\mathrm{Ca}(\mathrm{mmol} / \mathrm{l})$ & $2.43 \pm 0.08$ & $2.46 \pm 0.13$ & $>0.05$ \\
\hline $\mathrm{Ca}^{2+}(\mathrm{mmol} / \mathrm{l})$ & $1.26 \pm 0.09$ & $1.19 \pm 0.09$ & $>0.05$ \\
\hline $\mathrm{P}(\mathrm{mmol} / \mathrm{l})$ & $1.39 \pm 0.27$ & $1.38 \pm 0.24$ & $>0.05$ \\
\hline $\mathrm{Mg}(\mathrm{mmol} / \mathrm{l})$ & $0.81 \pm 0.09$ & $0.82 \pm 0.09$ & $>0.05$ \\
\hline $\mathrm{HbA} 1 \mathrm{c}(\%)$ & $10.89 \pm 1.76$ & $10.43 \pm 2.82$ & $>0.05$ \\
\hline Cholesterol $(\mathrm{mmol} / \mathrm{l})$ & $4.96 \pm 0.77$ & $4.48 \pm 1.12$ & $<\mathbf{0 . 0 5}$ \\
\hline Triacylglycerol $(\mathrm{mmol} / \mathrm{l})$ & $1.70 \pm 0.97$ & $1.11 \pm 0.75$ & $<\mathbf{0 . 0 5}$ \\
\hline BMI $\left(\mathrm{kg} / \mathrm{m}^{2}\right)$ & $20.97 \pm 3.71$ & $19.05 \pm 3.39$ & $<\mathbf{0 . 0 5}$ \\
\hline Vitamin D (ng/ml) & $29.52 \pm 10.03$ & $24.87 \pm 11.74$ & $>0.05$ \\
\hline Z score lumbar spine & $-1.06 \pm 1.18$ & $-0.89 \pm 1.37$ & $>0.05$ \\
\hline Z score femur & $-1.27 \pm 0.83$ & $-0.69 \pm 0.89$ & $>0.05$ \\
\hline
\end{tabular}

is competitive - high calcium intake may decrease magnesium absorption and low magnesium intake may increase calcium absorption. In our study, subjects with vitamin D deficiency had significantly lower magnesium concentration what may be explained by few hypotheses. First, hypomagnesemia may be predisposing factor for vitamin D deficiency and impaired bone density. Second, vitamin D deficiency may cause hypomagnesemia through decrease of intestine absorption. Third, magnesium concentration is related to diabetes mellitus and hyperglycemia causing hypermagnesiuria, however in our study no difference of diabetes compensation was found between subjects with lower and normal magnesium concentration.

T1D negatively influences the bone density and increases the risk of bone fractures. One of the consequences of diabetes as chronic disease is osteopenia caused by decreased osteoblastic acitivity while normal resorption ability. Osteopenia is related to deficit of insulin, which has anabolic function (27). Osteopenia is also seen in patients with insufficient diabetes compensation. Other possible interpretation of decreased bone density in diabetic patients is metabolic changes, for example advanced glycation end products in bone collagen, hypercalciuria associated with glycosuria and magnesiuria, inflammatory cytokines or diabetic microangiopathy with reduced blood supply of bone tissue (30). Possible cause of vitamin $\mathrm{D}$ defficiency in diabetic patients is also chronic diabetic complication - diabetic nephropathy. Danish authors claim negative correlation between decreased bone density and microalbuminury in adult patients with T1D (5), therefore diabetic patients with microalbuminury had significantly lower bone density. Diabetic osteopenia may be related to diabetic nephropathy as kidney ability to hydroxylate the vitamin $\mathrm{D}$ can be afflicted with consequence of insufficient formation of vitamin $\mathrm{D}_{3}$. In our study, we did not claim the influence of nephropathy on vitamin D deficiency what could be caused by incipient phase of nephropathy in young diabetic population.

\section{Conclusion}

In our study, nearly two thirds of children with type 1 diabetes mellitus had insufficient level of vitamin D with negatively influence on densitometric parameters. Diabetic patients should be monitored in vitamin $\mathrm{D}$ concentration and should be recommended to modificate their life-style with including the animal sources of vitamin D to their nutrition and to sunbath face and hands ten to twenty minutes daily according to the colour of the skin. If necessary, patients should be treated by vitamin $\mathrm{D}$ and magnesium supplement according to individual needs or during the winter and spring period.

\section{Acknowledgements}

The study was supported by project "Center of experimental and clinical respirology II", co-financed from EU sources.

\section{References}

1. Babusikova E, Jesenak M, Durdik P, Dobrota D, Banovcin P. Exhaled carbon monoxide as a new marker of respiratory diseases in children. Journal of Physiology and Pharmacology 2008; 59(suppl 6): 9-17.

2. Banovcin P. Diagnostic problems of bronchial asthma in infants, Lekarsky Obzor 1999; 48: 243-245.

3. Bener A, Alsaied A, Al-Ali M, Al-Kubaisi A, Basha B, Abraham A, Guiter G, Mian M. High prevalence of vitamin D deficiency in type 1 diabetes mellitus and healthy children. Acta Diabetologica 2009; 46: 183-189.

4. Bodnar LM, Catov JM, Zmuda JM, Cooper ME, Parrott MS, Roberts JM, Marazita ML, Simhan HN. Maternal serum 25-hydroxyvitamin D concentrations are associated with small-for-gestational age births in white women. J Nutr 2010; 140: 999-1006.

5. Clausen P, Feldt-Rasmussen B, Jacobsen P, Rossing K, Parving HH, Nielsen PK, Feldt-Rasmussen U, Olgaard K. Microalbuminuria as an early indicator of osteopenia in male insulin-dependent diabetic patients. Diab Med 1997; 14: 1038-1043. 6. Devaraj S, Yun JM, Duncan-Staley CR, Jialal I. Low vitamin D levels correlate with the proinflamatory state in type 1 diabetic subjects with and without microvascular complications. Am J Clin Pathol 2011; 135: 429-33.

7. Elisaf M, Milionis H, Siamopoulos KC. Hypomagnesemic hypokalemia and hypocalcemia: clinical and laboratory characteristics. Miner Electrolyte Metab 1997; 23: $105-12$. 
8. Erbağci AB, Tarakçioğlu M, Erbağci A, Gözübüyük M, Yilmaz N, Deveci R, Kocabas R. Triglycerides predict plasma fibronectin in children with type I diabetes mellitus rather than diabetes. Acta Medica (Hradec Kralove) 2002; 45: 33-7.

9. Furková K, Šašinka M. Svetová pandémia hypovitaminózy D. Detský lekár 2010; $17: 3-6$.

10. Gordon CM, Bachrach LK, Carpenter TO, Crabtree N, El-Hajj Fuleihan G, Kutilek S, Lorenc RS, Tosi LL, Ward KA, Ward LM, Kalkwarf HJ. Dual Energy X-ray Absorptiometry Interpretation and Reporting in Children and Adolescents: The 2007 ISCD Pediatric Official Positions. J Clin Densitom 2008; 11: 43-58

11. Hardwick LL, Jones MR, Brautbar N, Lee DB. Magnesium absorption: mechanisms and the influence of vitamin D, calcium and phosphate. J Nutr 1991 Jan; 121: 13-23.

12. Havlíčeková Z, Tonhajzerová I, Jurko A, Jeseňák M, Ďurdík P, Nosál’ S, Zeleňák K, Antošová M, Bánovčin P. Cardiac autonomic control in adolescents with primary hypertension. Eur J Med Res 2009; 14(suppl 4): 101-103.

13. Hypponen E, Berry DJ, Wist M, Power C. Serum 25-hydroxyvitamin D and IgEa significant but nonlinear relationship. Allergy 2009; 64: 613-20.

14. Ingraham BA, Bragdon B, Nohe A. Molecular basis of the potential of vitamin D to prevent cancer. Current Medical Research and Opinion 2008; 24: 139-149.

15. Institute of Medicine. Food and Nutrition Board. Dietary Reference Intakes: Calcium, Phosphorus, Magnesium, Vitamin D and Fluoride. Washington, DC: National Academy Press, 1997: 448

16. Jeseňák $M$, Antonyová $M$, Brndiarová $M$, Buchanec J, Bánovčin P. Henoch-Schönlein purpura from the standpoint of preventive corticoid administration. Cesko-Slovenska Pediatrie 2008; 63: 557-564.

17. Jesenák M, Bánovcin P. Atopy patch test in the diagnosis of food allergy in children with atopic dermatitis. Acta medica (Hradec Králové) 2006; 49: 199-201.

18. Jesenak M, Rennerova Z, Babusikova E, Havlicekova Z, Jakusova L, Villa MP, Ronchetti R, Banovcin P. Food allergens and respiratory symptoms. J Physiol Pharmacol 2008; 59(suppl. 6): 311-20.

19. Kemink SAG, Hermus ARM, Swinkels LM, Lutterman JA, Smals AGH. Osteopenia in insulin-dependent diabetes mellitus; prevalence and aspects of pathophysiology. J Endocrin Invest 2000; 23: 295-303.

20. Levin ME, Boisseau VC, Avioli LV. Effects of diabetes mellitus on bone mass in juvenile and adult-onset diabetes. N Eng J Med 1976; 294: 241-245.

21. Lips P. Vitamin D physiology. Prog Biophys Mol Biol 2006; 92: 4-8

22. Mikler J, Banovcin P, Jesenak M, Hamzikova J, Statelova D. Successful treatment of extreme acute lead intoxication. Toxicology and Industrial Health 2009; 25: $137-140$.

23. Mitri J, Dawson-Hughes B, Hu FB, Pittas AG. Effects of vitamin D and calcium supplementation on pancreatic $\beta$ cell function, insulin sensitivity, and glycemia in adults at high risk of diabetes: the Calcium and Vitamin D for Diabetes Mellitus (CaDDM) randomized controlled trial. Am J Clin Nutr 2011; 94: 486-494.

24. Motohashi Y, Yamada S, Yanagawa T, Maruyama T, Suzuki R, Niino M, Fukazawa T, Kasuga A, Hirose H, Matsubara K, Shimada A, Saruta T. Vitamin D Receptor Gene Polymorphism Affects Onset Pattern of Type 1 Diabetes. Journal of Clinical Endocrinology and Metabolism 2003; 88: 3137-3140.

25. Nikkoyeh B, Neyestani TR, Farvid M, Alavi-Majd H, Houshiarrad A, Kalayi A, Shariatzadeh N, Gharavi A, Heravifard S, Tayebinejad N, Salekzamani S, Zahedirad M. Daily consumption of vitamin D- or vitamin D + calcium-fortified yogurt drink improved glycemic control in patients with type 2 diabetes: a randomized clinical trial. Am J Clin Nutr 2011, 93: 764-771.

26. Razzaghy-Azar M, Shakiba M. Assessment of vitamin D status in healthy children and adolescents living in Tehran and its relation to iPTH, gender, weight and height. Ann Hum Biol 2010; 37: 692-701.

27. Rybka J. Diabetes mellitus - komplikace a přidružená onemocnění. 1st ed. Praha: Grada Publishing, 2007: 320.

28. Sales CH, Pedrosa LF, Lima JG, Lemos TM, Colli C. Influence of magnesium status and magnesium intake on the blood glucose control in patients with type 2 diabetes. Clin Nutr 2011; 30: 359-64.

29. Skálová S. The diagnostic role of urinary N-acetyl-beta-D-glucosaminidase (NAG) activity in the detection of renal tubular impairment. Acta Medica (Hradec Kralove) 2005; 48: 75-80.

30. Svoren BM, Volkening LK, Wood JR, Laffel LM. Significant vitamin D deficiency in youth with type 1 diabetes mellitus. J Pediatr 2009; 154: 132-134.

31. Tucker KL, Hannan MT, Chen H, Cupples LA, Wilson PW, Kiel DP. Potassium, magnesium, and fruit and vegetable intakes are associated with greater bone mineral density in elderly men and women. Am J Clin Nutr 1999; 69: 727-36.

32. Walker VP, Modlin RL. The Vitamin D Connection to Pediatric Infections and Immune Function. Pediatr Res 2009; 28: 106-113.

33. Wang TJ, Pencina MJ, Booth SL, Jacques PF, Ingelsson E, Lanier K, Benjamin EJ, D'Agostino RB, Wolf M, Vasan RS. Vitamin D Deficiency and Risk of Cardiovascular Disease. Circulation 2008; 117: 503-511.

34. Yoho RM, Frerichs J, Dodson NB, Greenhagan R, Geletta S. A comparison of vitamin $\mathrm{D}$ levels in nondiabetic and diabetic patient population. J Am Pediatr Med Assoc 2009; 99: 35-41.

35. Zofková I, Kancheva RL. The relationship between magnesium and calciotropic hormones. Magnes Res 1995; 8: 77-84.

Received: 04/10/2011

Accepted in revised form: 30/11/2011

\section{Corresponding author:}

MUDr. Jarmila Vojtková, PhD., Department of Pediatrics, Comenius University in Bratislava, Jessenius Faculty of Medicine and University Hospital in Martin, Kollárova 2, 03601 Martin, Slovakia; e-mail: jarmilavojtkova@gmail.com 